\title{
MENCINTAI RASULULLAH SAW. DALAM PERSFEKTIF HADIS
}

(Kritik Sanad dan Matan Terhadap Hadis Riwayat Ibn Majah)

\author{
Makmur \\ Dosen STAIN Majene \\ Puaqqohir@stainmajene.ac.id
}

Nurjannah

(Mahasiswa Prodi Ilmu al-Qur'an dan Tafsir STAIN Majene)

\begin{abstract}
Abstrak
Tidaklah salah seorang dari kalian beriman hingga aku lebih dia cintai daripada anaknya, orang tuanya dan manusia semuanya. Demikian bunyi hadis Nabi yang terekam dalam kitab Ibn Majah pada bab fi alIman. Namun dalam memahami hadis dibutuhkan penelitian yang mendalam sebab hadis tidak sekuat Alquran yang telah memproklamirkan dirinya sebagai kitab yang kebenarannya la raiba fih. Dari permasalahan tersebut penelitian ini bertujuan untuk mengetahui bagaimana kualitas dan kandungan hadis yang diriwatkan oleh Ibn Majah di atas. Dalam mengumpulkan data ditempuh dengan menggunakan metode takhrij al-hadis yang diolah melalui kritik sanad dan matan. Adapun pendekatan yang digunakan bersifat holistik dan multidisipliner. Sedangkan teknik interpretasinya meliputi tekstual dan kontekstual. Hasil penelitian menunjukkan bahwa hadis tersebut berjumlah 13 riwayat yang tertuang dalam beberapa kitab yaitu; sahih al-Bukhari, sahih al-Muslim, aunan al-Nasai, sunan ibn Majah, sunan Ahmad ibn Hanbal, dan sunan al-Darimi. Dari 13 riwayat tersebut peneliti melakukan kritik terhadap hadis yang diriwayatkan oleh Ibn Majah dari jalur Anas ibn Malik yang berstatus sahih.
\end{abstract}

Kata kunci: Mencintai, Rasulullah, Hadis.

\section{A. Pendahuluan}

Pada dasarnya, fitrah hati manusia mencintai kesempurnaan. Allah swt., adalah zat pemilik segala kesempurnaan, tidak ada kekurangan walaupun setitik. Allah swt., Maha indah dan tidak ada yang lebih indah dari-Nya. Bahkan apabila seluruh keindahan yang ada pada seluruh makhluk-Nya dihimpun menjadi satu, tetap tidak akan menandingi ke-Mahaindahan Allah swt. Kalaupun harus 
diperbandingkan antara keindahan-Nya dengan keindahan seluruh makhluk, maka laksana matahari berdampingan dengan lilin kecil yang redup. ${ }^{1}$

Dalam konteks tersebut, al-Gazali memadahkan obyek yang paling layak dicintai adalah Allah swt., karena semua sebab yang memotivasi manusia untuk mencintai sesuatu di dunia ini, maka Allah swt., memiliki semua itu secara sempurna, bahkan ke-Maha sempurnaan-Nya melebihi semua kesempurnaan yang bisa dijangkau oleh pikiran manusia. ${ }^{2}$

Setelah cinta kepada Allah, dalam kulminasi kemuliaan, kesucian dan keagungan adalah cinta kepada Rasulullah saw. yang diutus sebagai pembawa rahmat bagi alam semeseta. ${ }^{3}$ Merupakan hal yang logis jika cinta kepada Allah harus diikuti dengan cinta kepada Rasul-Nya sebab dialah makhluk termulia di antara para makhluk, dan dia pula yang memiliki akhlak mulia serta petunjuk jalan lurus. ${ }^{4}$ Dari itulah, seorang muslim belum dikatakan sempurna imannya sebelum ia mencintai Rasulullah saw., melebihi cintanya kepada orang lain dan kepada dirinya sendiri. Diriwayatkan dari Anas bin Malik ra. bahwasanya Rasulullah saw., bersabda:

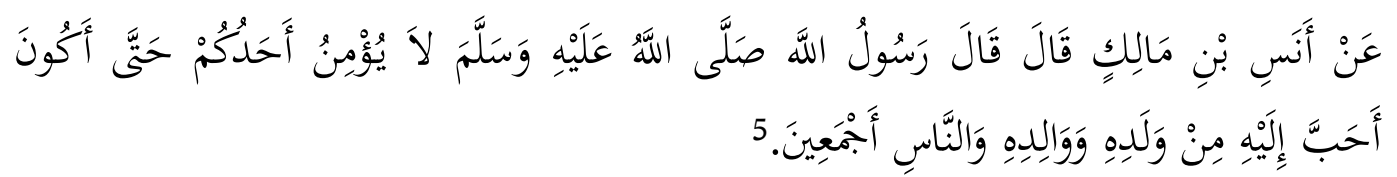

Artinya:

Dari Anas ibn Malik dia berkata, Rasulullah saw., bersabda: Tidaklah salah seorang dari kalian beriman hingga aku lebih dia cintai daripada anaknya, orang tuanya dan manusia semuanya.

Hadis di atas menjelaskan bahwa seseorang belum dikatakan beriman secara kaffah sebelum ia mencintai Rasulullah saw., melebihi cintanya kepada

${ }^{1} \mathrm{Abu}$ 'Abd Allah Muhammad ibn Abu Bakar Ayyub al-Zar'i Ibn Qayyim Jauziyah, Raudat al-Muhibbin wa Nuzhat al-Musytaqin (Beirut: Dar al-Kutub al-'Ilmiyah, 1412 M/ 1992). h. 418.

${ }^{2}$ Al-Gazali, Ihya' 'Ulum al-Din, Juz. IV (Beirut: Dar al-Ma'rifah, t. th.), h. 300.

${ }^{3}$ Tasbih, Menemukan Hakekat Cinta Melalui Hadis Nabi Saw, (Jakarta: Orbit Publishing, 2010), h. 44.

${ }^{4}$ Ahmad Nashib al-Mahamid, al-Hubb baina al-Abd wa al-Rabb, Terj. Ahmad Zubaidi, Memadu Cinta di Taman Islam (Cet: I; Solo: Era Intermedia, 2002), h.164.

${ }^{5} \mathrm{Abu}$ 'Abdillah Muhammad ibn Yazid al-Qazwini Ibn Majah, Sunan Ibn Majah, bab fi alIman, Juz. I (Beirut: Dar al-Fikr, t.th.), h.26. Selanjutnya disebut Ibn Majah. 
diri sendiri. Namun, dalam memahami sebuah hadis dibutuhkan penelitian yang mendalam sebab hadis tidak sekuat Alquran yang telah memproklamirkan dirinya sebagai kitab yang kebenarannya la raiba fih. ${ }^{6}$

Dalam interval waktu yang cukup panjang antara wafatnya Nabi saw., dengan kodifikasi hadis secara resmi tentu menimbulkan berbagai hal yang dapat menjadikan riwayat hadis itu menyalahi apa yang sebenarnya berasal dari Nabi. Oleh karena itu, pengumpulan, penelitian, pemahaman dan pemaknaan ulang terhadap teks sebuah hadis, baik dari segi sanad dan matan serta kandungan maknanya sangat penting. Dengannya dapat diketahui kualitas sebuah hadis, apakah dapat dianggap sahih, hasan atau daif. ${ }^{7}$ Pengetahuan tentang kualitas hadis merupakan sebuah keharusan dalam menentukan boleh tidaknya hadis tersebut dijadikan hujjah.

Berdasarkan uraian di atas penulis akan melacak keotentikan hadis Nabi yang terdapat dalam kitab sunan ibn Majah pada kitab al-Iman no 67 tentang keharusan mencintai Rasulullah saw., melebihi kecintaan kepada keluarga dan kepada diri sendiri.

\section{B. Pembahasan}

\section{Pengertian}

Cinta berasal dari bahasa sansakerta, yaitu citta yang berarti " yang selalu dipikirkan; senang; kasih. ${ }^{8}$ Dalam Kamus Besar Bahasa Indonesia cinta memiliki beberapa makna, a. Suka sekali, sayang benar, b. Kasih Sekali, terpikat (antara

${ }^{6}$ Lihat: Q.S. al-Baqarah /1: 2.

${ }^{7}$ Hadis sahih adalah hadis yang sanadnya bersambung, diriwayatkan oleh periwayat yang 'adil, dabit dan tidak mengandung syadz dan 'illat. Adapun Hadis Hasan merupakan hadis yang padanya terpenuhi semua kriteria kesahihan hadis kecuali pada kriteria ke-dabitan periwayatnya tidak mencapai kualitas tam (sempurna) yakni: kurang sedikit, maksudnya tidak mencapai 100 persen tingkat kedabitan periwayatnya. ${ }^{7}$ Hadis Dai 'f adalah hadis yang tidak berkumpul padanya sifat hadis sahih dan hasan karena hilangnya salah satu syarat-syaratnya.

Lihat Lihat Muhammad 'Ajjaj al-Khatib, Usul al-Hadis: 'Ulumuh wa Mustalahahu (Beirut: Dar al-Fikr, 1409 H/1989 M.), h. 304.-337

${ }^{8}$ Abdurrasyid Ridha, Memasuki Makna Cinta (Cet: III; Yogyakarta: Pustaka Pelajar, 2004), h. 13. 
laki-laki dan perempuan) c. ingin sekali, berharap sekali; rindu, dan d. susah hati khawatir tiada terperikan lagi. ${ }^{9}$

Cinta lebih dari sekedar kasih dan sayang. Dalam cinta, selain ada unsur rindu, terdapat pula unsur penekanan yaitu; sangat ingin bertemu dan sangat suka yang membedakannya dengan kasih sayang. ${ }^{10}$

Dalam bahasa arab, bahasa yang digunakan oleh Nabi dalam bertutur, cinta diterjemahkan dengan al-hubb atau al-mahabbah.

Secara etimologi kata al-mahabbah merupakan bentuk masdar dari kata $h u b b$ kata yang memiliki tiga makna, yaitu: a) membiasakan dan tetap, b) biji dari sesuatu yang memiliki biji, dan c) sifat keterbatasan. ${ }^{11}$

Pengertian pertama mengandung makna bahwa dengan melazimi sesuatu secara tetap akan menimbulkan keakraban, yang kemudian membawa kepada persahabatan yang akhirnya dapat menimbulkan rasa cinta. Membiasakan sesuatu akan dapat menimbulkan keakraban yang merupakan awal dari munculnya rasa al-mahabbah atau keinginan bersatu. ${ }^{12}$

Sedang pengertian kedua yang mengatakan bahwa asal dari al-mahabbah adalah biji yang memiliki fungsi sebagai benih kehidupan bagi tumbuhtumbuhan, cinta merupakan benih kehidupan manusia yang mendorong lahirnya keinginan yang kuat untuk bertemu dan bersatu dengan sang kekasih yang diiringi dengan kerelaan dalam memberikan yang terbaik.

Adapun pengertian ketiga yang berarti sifat keterbatasan, dapat dipahami dengan melihat manusia sebagai subjek cinta, sangat terbatas dalam meraih sesuatu yang dicintai sehingga membutuhkan bantuan sang pemilik cinta yang sesungguhnya, yaitu Allah swt.

Sedangkan secara terminologi al-mahabbah sebagaimana yang didefinisikan oleh beberapa ahli di antaranya adalah: al-Gazali sebagai salah seorang tokoh sufi mengatakan, cinta adalah suatu kecenderungan terhadap

\footnotetext{
${ }^{9}$ Departemen pendidikan Nasional, Kamus Besar Bahasa Indonesia Pusat Bahasa (Jakarta ; Gramedia Pustaka Utama, 2008), h. 288.

${ }^{10}$ Abdurrasyid Ridha, Memasuki Makna Cinta ... h. 14.

${ }^{11}$ Lihat Abu al-Husain Ahmad ibn Faris Ibn Zakariyya, Mu'jam Maqayis al-Lugah, Juz. II (Beirut: Dar al-Fikr, 1971), h. 26.

${ }^{12}$ Rahmi Damis, Tasawuf (Cet. I; Makassar: Alauddin University Press, 2013), h. 117.
} 
sesuatu yang memberikan manfaat. Apabila kecenderungan itu mendalam dan menguat, maka ia dinamakan rindu. ${ }^{13}$

Harun Nasution memaknai cinta sebagai; kepatuhan pada Tuhan dan membenci sikap melawan kepada-Nya, menyerahkan seluruh diri kepada yang dikasihi dan mengosongkan hati dari segala-galanya kecuali dari yang dikasihi, yaitu Tuhan. ${ }^{14}$

Rabiatul adawiah seorang sufi wanita yang mashur dan dianggap sebagai penggagas konsep al-Mahabbah pernah ditanya tentang cinta, maka ia menjawab Antara orang yang mencintai dan yang dicintai tidak ada jarak. Ia adalah ungkapan kerinduan dan gambaran perasaan terdalam. ${ }^{15}$

Kahlil Gibran mengungkapkan bahwa cinta mengarahkan manusia kepada Allah dan karena cinta pula Allah mempertemukan diri-Nya dengan manusia. Lantaran itu, dalam pandangan Gibran, cinta sesungguhnya adalah cinta atas nama Allah dan cinta kepada Allah itu sendiri karena segala sesuatu adalah pantulan dan imanensi dari Sang Maha Cinta. ${ }^{16}$

Erich Fromm (1900-1980), seorang psiakiater yang merupakan tokoh dalam ahli psikologi humanistik mengatakan cinta adalah penembusan aktif kedalam pribadi lain hingga mengalami rasa persatuan. Menurutnya, cinta yang matang memuat beberapa komponen yang saling bergantung satu sama lain, yakni pengasuhan, perhatian, tanggung jawab, dan pengenalan terhadap pribadi lain. ${ }^{17}$

Dari uraian di atas, terlihat bahwa defenisi tentang cinta sangat beragam dan bersifat subyektif. Perbedaan tersebut bisa jadi disebabkan cinta tidak dapat dideteksi, kecuali melalui gejala-gejala psikologis, sifat-sifat, perilaku dan pengaruh yang di akibatkan pada diri seseorang yang mengalaminya. Bahkan

${ }^{13} \mathrm{Al}-$ Gazali, Ihya' 'Ulum al-Din, Juz. IV, h. 296.

${ }^{14}$ Harun Nasution, Falsafat dan Mistisisme dalam Islam (Cet. IV; Jakarta: Bulan Bintang, 1985), h. 70.

${ }^{15}$ Mahmud ibn al-Syarif, al-Hubb fi Alquran, Terj. Yusuf Hanafi dan Abdul Fattah, Alquran Bertutur Tentang Cinta (Cet. I; Yogyakarta: Cahaya Hikmah, 2003), h. 45.

${ }^{16}$ Sabrina Maharani, Filsafat Cinta (Cet. I; Jogjakarta: Garasi, 2009). h. 46.

${ }^{17}$ Sabrina Maharani, Filsafat Cinta...h. 29. 
sementara pakar berkata, keterangan tentang cinta bukanlah cinta. ${ }^{18}$ Bisa jadi ini benar, ketika seseorang hendak memaknai cinta dengan makna yang sempurna lagi tepat. Sebab bagaimana mungkin melukiskan segala sesuatu yang dirasakan dalam hati dan bukan hanya satu hati, tetapi seluruh hati manusia.

Dari beragam pandangan di atas, dapat disimpulkan bahwa dalam cinta terdapat beberapa unsur yang bisa membedakannya dengan yang lain, di antaranya dalam cinta ada ketertarikan, kekaguman, kesenangan, pengorbanan, perasaan selalu ingin bertemu, ada unsur ketaatan dan sebagainya.

\section{Takhrij al-Hadis}

Secara etimologis, kata takhrij berasal dari bahasa arab yang memiliki beberapa makna di antaranya; mengeluarkan, memberitahukan dan mendidik atau bermakna memberikan warna berbeda. ${ }^{19}$

Sedangkan secara terminologi takhrij adalah mengemukakan letak asal hadis pada sumbernya yang asli, yakni berbagai kitab, yang di dalamnya dikemukakan hadis itu secara lengkap dengan sanadnya masing-masing, kemudian untuk kepentingan penelitian maka dijelaskan kualitas hadis yang bersangkutan..$^{20}$

Dengan demikian, takhrij al-hadis dalam pembahasan ini adalah penelusuran atau pencarian hadis pada berbagai kitab hadis sebagai sumber asli yang di dalamnya dikemukakan secara lengkap sanad dan matan hadis yang diteliti.

Dari beberapa metode takhrij al-hadis yang dapat digunakan untuk menelusuri hadis dari sumbernya, ${ }^{21}$ penulis menggunakan metode takhrij al-hadis

${ }^{18}$ M. Quraish Shihab, Secercah Cahaya Ilahi, Hidup Bersama Alquran (Cet. I; Bandung: Mizan, 2013), h. 156.

${ }^{19}$ Ahmad Warson Munawwir, Kamus al-Munawwir Arab-Indonesia, Edisi ke II (Cet. XIV; Surabaya: Pustaka Progressif, 1997), h. 356; Muhmmad ibn Mukrim ibn Manzur, Lisan al'Arab, Juz. II (Cet. I; Beirut: Dar Sadir, t. th.), h. 249.

${ }^{20}$ M. Syuhudi Ismail, Metodologi Penelitian Hadis Nabi, h. 39-41.

${ }^{21} \mathrm{Abu}$ Muhammad Abd al-Mahdi mengemukakan lima macam metode takhrij al-Hadis yaitu: 1) Takhrij menurut lafal pertama hadis; 2) takhrij menurut lafal-lafal yang terdapat dalam matan hadis; 3) takhrij menurut periwayat terakhir; 4) takhrij menurut tema hadis; 5) takhrij menurut klasifikasi jenis hadis. Selanjutnya lihat; Abu Muhammad Mahdi 'Abd al-Qadir ibn 'Abd al-Hadi, Turuq Takhrij Hadis Rasulillah saw. Terj. Said Aqil Husain Munawwar dan Ahmad Rifqi Mukhtar, Metode Takhrij Hadis (Cet. I; Semarang: Dina Utama, 1994 M.), h. 15. 
bi al-lafz (takhrij menurut lafal-lafal yang terdapat dalam hadis) dengan merujuk kepada kitab al-Mujam al-Mufahras li Alfaz al-Hadis. Selanjutnya penulis melengkapinya dengan menggunakan program maktabah al-Syamilah.

Dari penelusuran dalam kitab al-Mu'jam al-Mufahras dengan menggunakan lafalأحب, didapatkan petunjuk sebagai berikut:

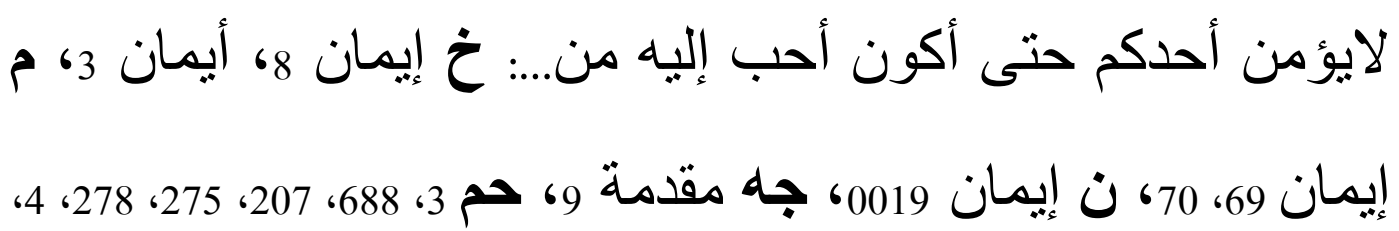

a. Klasifikasi Hadis

Setelah melakukan penelusuran hadis ke kitab sumber melalui metode takhrij al-hadis bi al-lafz dengan batasan kitab sumber yaitu Kutub al-Tis'ah ${ }^{23}$ maka ditemukan hadis dengan letak yang berbeda yaitu:

1. Teks hadis dari kitab Sahih al-Bukhari.

$$
\begin{aligned}
& \text { - حدثنا أبو اليمان قال أخبرنا شعيب قال حدثنا أبو الزناد عن الأعرج عن أبي هريرة رضي الله } \\
& \text { عنه أن رسول الله صلى الله عليه و سلم قال : فوالذي نفسي بيده لا يؤمن أحدكم حتى أكون } \\
& \text { أحب إليه من والده وولده. } \\
& \text { - حدثنا يعقوب بن إبراهيم قال حدثنا ابن علية عن عبد العزيز بن صهيب عن أنس عن النبي } \\
& \text { صلى الله عليه و سلم. قال قال البي صلى الله عليه و سلم : لا يؤمن أحدكم حتى أكون } \\
& \text { أحب إليه من والده وولده والناس أجمعين. } 24
\end{aligned}
$$

2. Teks hadis dari kitab Sahih al-Muslim

${ }^{22}$ A.J. Wensinck Diterjemahkan oleh Muhammad Fuad 'Abd al-Baqi, Mu jam alMufahras li Alfaz al-Hadis al-Nabi, Juz. I (Brill: Laeden, 1936 H.), h. 405-410.

${ }^{23}$ Yang termasuk dalam al-kutub al-tis'ah adalah (Bukhari, Muslim, Sunan Abu Daud, Sunan Tirmizi, Sunan al-Nasa'i dan, Sunan Ibn Majah)

${ }^{24} \mathrm{Abu}$ 'Abdillah Muhammad bin Isma'il al-Bukhari, Sahih al-Bukhari, kitab Iman, bab hubb al-rasul saw., min al-Iman, Juz. I (Cet. III; Beirut: Dar Ibn Kasir, 1407 H./1987 M.), h. 12. Selanjutnya disebut al-Bukhari. 


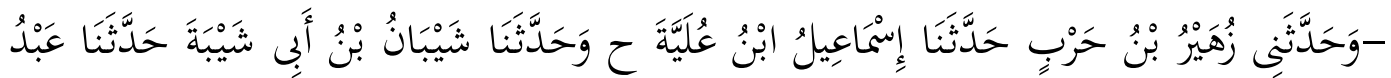

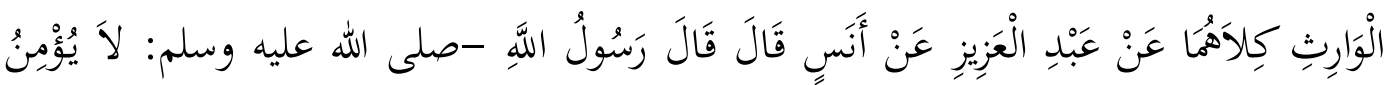

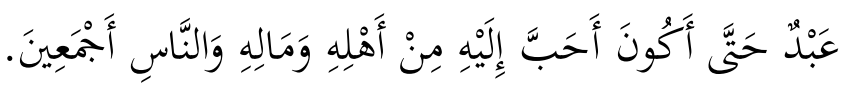

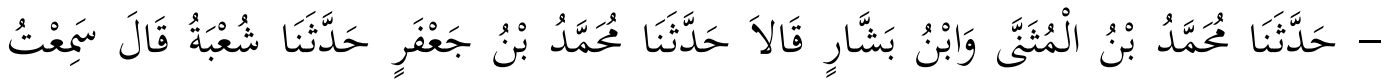

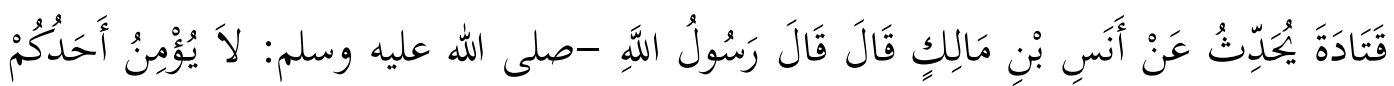
25

3. Teks hadis dari kitab Sunan al-Nasai - أخبرنا حميد بن مسعدة قال حدثنا بشر يعني بن المفضل قال حدثنا شعبة عن قتادة أنه سمع أنسا يقول قال رسول الله صلى الله عليه و سلم : لا يؤمن أحدكم حتى أكون أحب إليه من ولده ووالده والناس أجمعين.

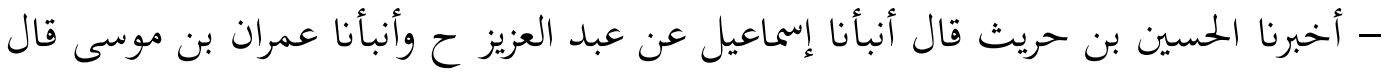

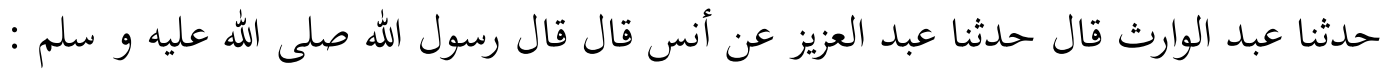
لا يؤمن أحدكم حتى أكون أحب إليه من ماله وأهله والناس أمعبين.

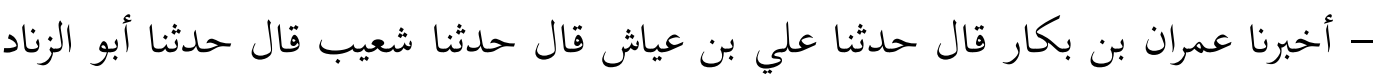

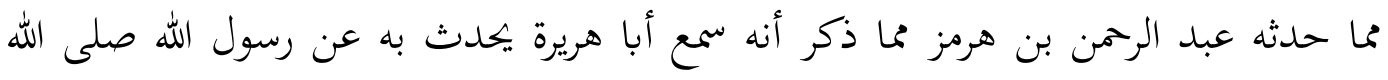
عليه و سلم قال : والذي نفسي بيده لا يؤمن أحدكم حتى أكون أحب إليد إليه من ولده ووالده.

4. Teks hadis dari kitab sunan Ibn Majah

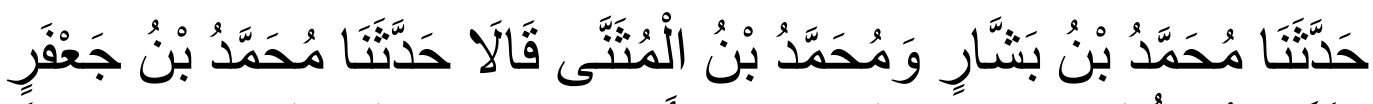

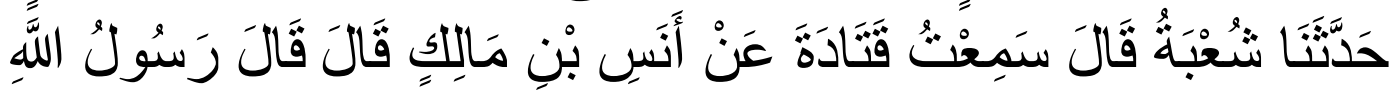

${ }^{25} \mathrm{Abu}$ al-Husain Muslim ibn al-Hajjaj ibn Muslim al-Qusyairi al-Naisaburi, Sahih Muslim, bab wujubu mahabbat al-Rasul aksar min al-ahl, Juz. I, (Beirut: Dar al-Jil, t.th.), h. 67. Selanjutnya disebut Muslim.

${ }^{26} \mathrm{Abu}$ Abd al-Rahman Ahmad ibn Syuaib ibn Ali al-Khurrasani al-Nasai, Sunan alNasai bab 'alamat al-iman, Juz. VIII, (cet. II; Hilb: Maktabah al-Matbua al-Islamiyah, 1986), h. 114 dan 115. Selanjutnya disebut al-Nasai. 


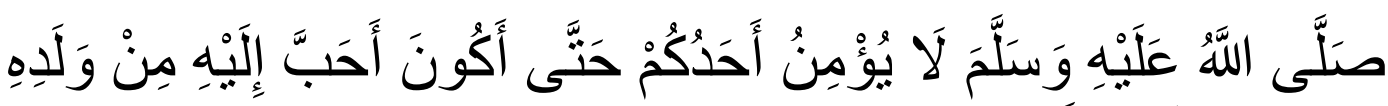 وَوَ اللِِهِ وَ النَّاسِ أَجْمَعِبِنَ.}

5. Teks hadis dari kitab Sunan Ahmad ibn Hanbal

- حدثنا عبد الله حدثني أبي ثنا محمد بن جعفر ثنا شعبة وحجاج قال حدثني شعبة قال سمعت قتادة يحدث عن أنس بن مالك قال قال رسول الله صلى الله عليه و سلم : لا يؤمن أحدكم حتى أكون أحب إليه من والده وولده والناس أجمعين. - حدثنا عبد الله حدثني أبي ثنا روح ثنا شعبة ثنا قتادة عن أنس بن مالك عن النبي صلى الله عليه و سلم أنه قال : لا يؤمن أحدكم حتى يكون الله ورسوله أحب إليه مما سواهما وحتى يقذف في النار أحب إليه من أن يعود في الكفر بعد أن نجاه الله منه ولا يؤمن أحدكم حتى أكون أحب إليه من ولده ووالده والناس أجمعين.

- - حدثنا عبد الله حدثني أبي ثنا محمد بن جعفر ثنا شعبة وحجاج قال حدثني شعبة قال سمعت قتادة يحدث عن أنس بن مالك قال قال رسول الله صلى الله عليه و سلم : لا يؤمن أحدكم حتى أكون أحب إليه من ولده ووالده والناس أجمعين. - حدثنا عبد الله حدثني أبي ثنا روح ثنا شعبة ثنا قتادة عن أنس بن مالك عن النبي صلى الله عليه و سلم قال : لا يؤمن أحدكم حتى يكون الله ورسوله أحب إليه مما سواهما وحتى يقذف في النار أحب إليه من أن يعود في كفر بعد إذ نجاه الله منه ولا يؤمن أحدكم حتى أكون أحب إليه من ولده ووالده والناس أجمعين. 28

6. Teks hadis dari kitab Sunan al-Darimi.

- أخبرنا يزيد بن هارون وهاشم بن القاسم قالا ثنا شعبة عن قتادة عن أنس عن النبي صلى الله عليه و سلم قال : لا يؤمن أحدكم حتى أكون أحب إليه من والده وولده والناس أجمعين.

\section{b. I'tibar Hadis}

${ }^{27}$ Ibn Majah, Sunan Ibn Majah, bab fi al-Iman, Juz. I h.26.

${ }^{28} \mathrm{Abu}$ 'Abdillah Ahmad ibn Muhammad ibn Hanbal, Musnad Ahmad ibn Hanbal, bab musnad Anas ibn Malik ra., Juz. III, (Cet. I; Beirut: 'Alam al-Kutub, 1419 H./1998 M.), h. 177, 207, 275 dan 278. Selanjutnya disebut Ahmad.

${ }^{29}$ Abu Muhammad abd Allah ibn abd al-Rahman ibn al-Fadhl ibn Bahram ibn abd alSamad al-darimi, Sunan al-Darimi, bab La yu'min Ahadukum hatta yuhibb li akhihi ma yuhibb linafsihi, juz III (Cet. I; Saudi: Dar al-Mugni, 2000 ), h. I801. Selanjutnya disebut al-Darimi. 
Langkah selanjutnya adalah kritik hadis dan hal-hal yang terkait dengannya, maka penulis akan memaparkan hadis yang menjadi objek kajian yaitu;

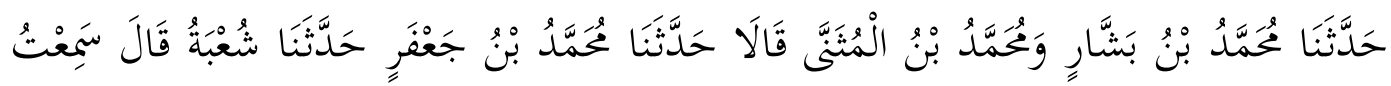

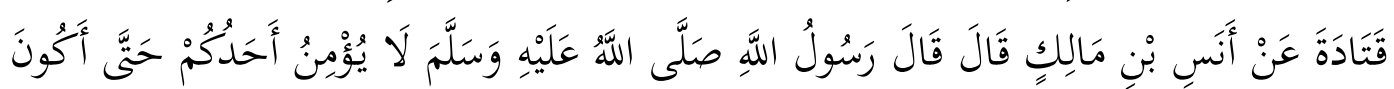

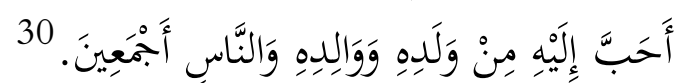

Setelah menelusuri lebih jauh dalam kutub al-tisah, hadis tersebut di atas ditemukan sebanyak 13 riwayat, antara lain 2 riwayat dalam Sahih al-Bukhari, 2 riwayat dalam Sahih al-Muslim, 3 riwayat dalam Sunan al-Nasai, 1 riwayat dalam Sunan ibn Majah, 4 riwayat dalam Sunan Ahmad ibn Hanbal, dan 1 riwayat dalam Sunan al-Darimi.

Dari 13 riwayat tersebut ditemukan, sahabat yang meriwayatkan hadis tersebut ada dua yaitu Anas ibn Malik dan Abu Hurairah. Dan yang menjadi objek kajian adalah Anas bin Malik, sedangkan pada level setelahnya, ada 4 tabiin yaitu al-Araj, Abd al-Aziz ibn Suhaib, Qatadah dan Abd al-Rahman ibn Harmaz. Dengan demikian, hadis ini memiliki 1 syahid dan 3 mutabi. Untuk lebih jelasnya, berikut skema sanad dari hadis yang menjadi objek kajian: (lihat halam lampiran)

${ }^{30}$ Ibn Majah, Sunan Ibn Majah, bab fi al-Iman, h. 26. 


\section{c. Kritik Hadis}

Langkah berikutnya adalah kritik hadis (Naqd al-Hadis) yang lebih dikenal dengan istilah kritik sanad dan matan. Dengan melakukan kritik hadis dapat diketahui mana hadis yang sahih dan mana hadis yang tidak sahih dan berikutnya hadis yang sahih dijadikan hujjah, sedangkan hadis yang tidak sahih tidak dijadikan hujjah. Lebih jelasnya, berikut kritik sanad dan matan dari hadis yang diteliti;

\section{Kritik sanad}

Dalam penelitian sanad, penulis mengacu pada kaedah kesahihan sanad menurut Syuhudi Ismail yang meliputi sanadnya bersambung, seluruh periwayat dalam sanad bersifat 'adil, seluruh periwayat dalam sanad bersifat dabit. Adapun terhindar dari syuzuz dan'illat termasuk dalam kaidah minor dari periwayat yang bersifat dabit. ${ }^{31}$ Maka dari itu, suatu sanad hadis yang tidak memenuhi unsur tersebut adalah hadis yang kualitas sanadnya tidak sahih. Adapun sanad hadis yang akan diteliti adalah:

a) Ibn Majah

Nama lengkapnya adalah Abu 'Abdillah Muhammad ibn Yazid ibn Majah al-Raba'iy al-Qazwini. (207 H/ 824 M.- 273 H.) Di antara gurunya adalah Muhammad ibn Basysyar Bundar. Ulama kritikus hadis seperti; al-Zahabi dan Ibn Hajar menilainya dengan lafaz ta'dil al-hafiz. Tidak ditemukan ulama yang mencela kedabitan dan keadilannya. ${ }^{32}$

b) Muhammad ibn Basysyar

Nama lengkapnya adalah Muhammad ibn Basysyar ibn 'Usman ibn Daud ibn Kaisan al-'Abdi, Abu Bakar al-Hafiz al-Basari Bundar. (167 H- 252 H) Semasa hidupnya dia pernah belajar kepada Muhammad ibn Ja'far Gundar dan menjadi guru bagi Ibn Majah. Komentar ulama terhadap dirinya antara lain

\footnotetext{
${ }^{31}$ Adapun kaidah minor untuk sanad bersambung: muttasil, marfu', mahfuz dan bukan mu'al. Lihat. M. Syuhudi Ismail, Kaedah Kesahihan Hadis: Telaah Kritis dan Tinjauan dengan Pendekatan Sejarah, h. 155-156.

${ }^{32}$ Abu al-Fadl Ahmad ibn Hajar al-'Asqalani, Tahzib al-Tahzib, Juz. IX (Beirut: Dar alFikr, 1984), h. 468. Selanjutnya disebut Ibn Hajar.
} 
disampaikan oleh; Abu Hatim menilainya saduq. Al-Nasai mengatakan salihun laba'sa bih. Al-'Ijli, Ibn Sayyar dan Ibn Hajar mengatakan siqah. Dalam periwayatan hadis ia termasuk kedalam tabaqat ke-10. ${ }^{33}$

c) Muhammad ibn Ja'far

Nama lengkapnya adalah Muhammad ibn Ja'far al-Huzali, Maulahum Abu 'Abdillah al-Basri yang dikenal dengan panggilan Gundar. (110 H-193 H.) Semasa hidupnya dia pernah belajar kepada Syu'bah ibn al-Hajjaj, selama 20 tahun. Dan menjadi guru bagi Muhammad ibn Basysyar Bundar. Para ulama kritikus hadis seperti; Abu Hatim, Ibn Hajar menilainya dengan lafaz ta'dil. Tak satupun ulama yang menilainya cacat. ${ }^{34}$

d) Syu'bah

Nama lengkapnya adalah Syu'bah ibn al-Hajjaj ibn al-Warad al-'Ataki alAzdi Abu Bistam al-Wasiti. (83 H-160 H) Di antara gurunya adalah Qatadah ibn Di'amah sedangkan di antara muridnya adalah Muhammad ibn Ja'far Gundar. Komentar ulama terhadap dirinya antara lain dikemukakan oleh; al-'Ijli, Ibn Hajar dan Ibn Saad menilainya dengan predikat siqah. Bahkan al- Zahabi menilainya Imam, al-Hafiz, Amir al-Mu'minin fi al-Hadis. ${ }^{35}$

e) Qatadah

Nama lengkapnya adalah Qatadah ibn Di’amah ibn Qatadah ibn 'Aziz ibn 'Amru ibn Rabi'ah ibn 'Amru ibn al-Haris ibn Sadus. (60 H.- 117 H. ) Di antara gurunya adalah Anas ibn Malik dan di antara muridnya adalah Syu'bah ibn alHajjaj. Ulama kritikus hadis yang menilainya yaitu; Al-'Ijli dan Yahya ibn Ma'in mengatakan siqah. Al-Zahabi dan al-Zarkali mengatakan siqah, sabt, tetapi terkadang melakukan tadlis. ${ }^{36}$

\footnotetext{
${ }^{33} \mathrm{Abu}$ al-Hajjaj Yusuf ibn al-Zaki 'Abd al-Rahman al-Mizzi, Tahzib al-Kamal, Juz. XXIV, (Cet. I; Beirut: Muassasah al-Risalah, 1400 H./1980 M.), h. 511-517. Selanjutnya disebut al-Mizzi. Ibn Hajar al-'Asqalani, Tahzib al-Tahzib, Juz. III, h.519;

${ }^{34}$ al-Mizzi, Tahzib al-Kamal, Juz. XXV, h. 5-8; Ibn Hajar al-'Asqalani, Tahzib al-Tahzib, Juz. IX, h. 85-86.

${ }^{35}$ Yusuf al-Mizzi, Tahzib al-Kamal, Juz. XII, h. 490-493; Muhammad ibn Ahmad ibn 'Usman al-Zahabi, Tazkirat al-Huffaz, Juz. I (Cet. I; Beirut: Dar al-Kutub al-'Ilmiyah, 1998 M/ 1419 H), h. 144. Selanjutnya disebut 'Usman al-Zahabi.

${ }^{36}$ Lihat Yusuf al-Mizzi, Tahzib al-Kamal, Juz. XXIII, h. 515.
} 
f) Anas ibn Malik

Ia bernama lengkap Anas ibn Malik ibn al-Nadar ibn Damdam ibn Zaid ibn Haram ibn Jundub ibn Amir ibn Ganam ibn Adi ibn al-Najjar ibn Sa'labah ibn Amru ibn al-Khazraj. (10 S.H-93 H) Di antara gurunya adalah Rasulullah saw., sedangkan di antara muridnya adalah Qatadah. ${ }^{37}$

Dari jalur sanad hadis di atas, ditemukan semua rawinya mendapat penilaian terpuji dari para ulama kritik hadis, dan jarak tahun wafat antara guru dengan murid tidak terlalu berjauhan dan bisa diyakini mereka pernah hidup sezaman dan terjadi periwayatan hadis antara guru dan murid. Dengan demikian, sanad hadis yang diteliti dapat dinilai sahih.

\section{Kritik Matan}

Dalam penelitian matan, penulis berpijak pada kerangka kaidah mayor kesahihan matan hadis yaitu terhindar dari 'illat dan syaz. Adapun unsur-unsur kaidah minor bagi matan hadis yang terhindar dari'Illat adalah, matan hadis tersebut tidak mengandung idraj (sisipan), ziyadah (tambahan) pada matan yang bukan berasal dari Rasulullah saw; tidak terjadi maqlub (lafaz matan yang bertukar), tidak terjadi idtirab (pertentangan matan-nya dengan matan yang lain yang tidak dapat dikompromikan) dan tidak terjadi kerancuan lafal dan penyimpangan makna yang jauh dari matan hadis yang bersangkutan.

Sedangkan kaidah minor bagi matan hadis yang mengandung syaz adalah sanad hadis bersangkutan tidak menyendiri, tidak bertentangan dengan Alquran; tidak bertentangan dengan matan hadis yang sanadnya lebih kuat, tidak bertentangan dengan akal dan fakta sejarah. ${ }^{38}$

a) Kualitas sanad

${ }^{37} \mathrm{Abu}$ Nu'aim Ahmad ibn 'Abdillah ibn Ahmad ibn Ishaq ibn Musa ibn Mahra alAsbahani, Ma 'rifat al-Sahabah, Juz. I (Cet. I; Riyad: Dar al-Watan, 1998 M/1419 H), h. 231;

${ }^{38}$ Arifuddin Ahmad, Paradigam Baru Memahami Hadis Nabi Refleksi Pemikiran Pembaruan Prof. Dr. Muhammad Syuhudi Ismail (Cet. I; Jakarta: Renaisan, 2005), h. 117. 
Setelah melakukan penelitian terhadap sanad hadis yang menjadi objek kajian dalam tesis ini, tidak ditemukan masalah pada perawi-perawinya, karena semuanya dinilai siqah. Dengan demikian dari segi sanad hadis tersebut berkualitas sahih dan selanjutnya penelitian matan dapat dilakukan.

b) Penelitian lafal semakna.

Setelah membandingkan 13 varian lafal hadis di atas, maka ditemukan bahwa hadis tersebut tidak mengalami banyak perbedaan antara satu dengan فو الذي و الذي نفسي بيده ada juga yang memakai ada yang لأ لأ بؤ من أحدكم, ada juga yang memakai kata Kemudian pada kalimat terakhirnya ada yang mendahulukan kata من ماله و أهله و الناس مل Dengan demikian, dapat dipastikan bahwa hadis di atas diriwayatkan bi al-ma'na. Olehnya itu, matan hadis yang diteliti terhindar dari 'illah.

c) Penelitian Kandungan Matan

Selain selamat dari 'illah/ penyakit, kandungan hadis di atas secara umum juga tidak menglami syuzuz (berbeda dengan hadis yang lebih siqah). Hal itu dapat dilihat bahwa hadis yang menjadi objek kajian tidak bertentangan dengan ayat-ayat Alquran secara makna bahkan sejalan dengan Firman Allah swt., dalam QS. Al-Ahzab /33: 6 yang menyatakan Nabi itu (hendaknya) lebih utama bagi orang-orang mukmin dari diri mereka sendiri.

Begitu juga hadis di atas tidak bertentangan dengan hadis sahih bahkan sejalan dan sesuai dengan hadis sahih yang diriwayatkan oleh Imam al-Bukhari. 


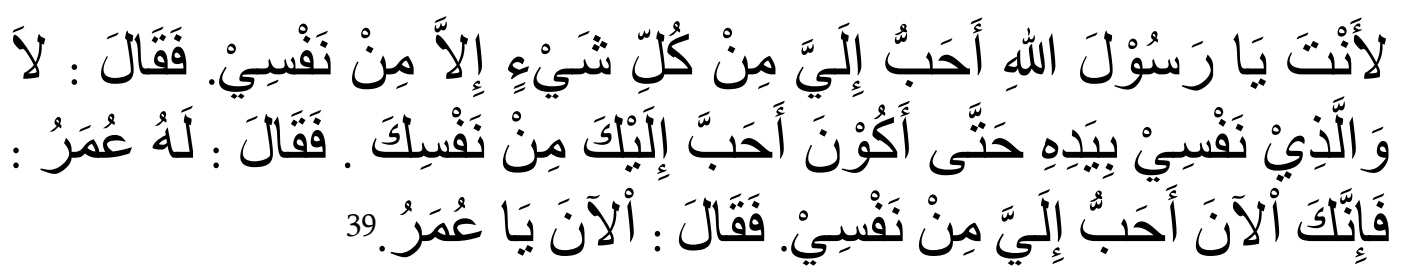

Artinya:

Sesungguhnya engkau wahai Rasulullah, adalah orang yang paling aku cintai daripada segala sesuatu selain diriku sendiri." Nabi saw., bersabda, 'Tidak, demi Zat yang jiwaku ada di Tangan-Nya, sehingga aku lebih engkau cintai dari dirimu sendiri'. Maka 'Umar berkata kepada beliau, 'Sekarang ini engkau lebih aku cintai daripada diriku sendiri. Maka Nabi saw., bersabda: Sekarang (telah sempurna kecintaanmu (imanmu) padaku) wahai 'Umar.

Di samping itu, secara logika hadis di atas sangat dibenarkan dimana mencintai kekasihnya kekasih, sama dengan mencintai sang kekasih. Dengan demikian, mencintai Rasulullah saw., sebagai kekasihnya sang kekasih berarti mencintai Allah swt sebagai sang kekasih. Berdasarkan kenyataan tersebut sangat rasional ketika manusia dituntut untuk mencintai Rasullullah saw., melebihi cintanya kepada keluarga bahkan kepada dirinya sendiri..

d) Hasil kritik

Berdasarkan kritik sanad dan matan yang telah dilakukan, penulis berkesimpulan bahwa hadis yang menjadi objek penelitian memenuhi unsur kesahih-an hadis, baik dari segi sanad maupun matan dengan demikian hadis tersebut berstatus sebagai hadi sahih.

\section{Kandungan Hadis}

Mencintai Nabi saw., merupakan bagian integral dari iman. Seseorang belum dikatakan sempurna imannya sebelum ia mencintai Rasulullah saw., melebihi cintanya kepada harta benda, keluarga, dan bahkan kepada diri sendiri. Hal tersebut berlandaskan pada hadis Nabi saw.,

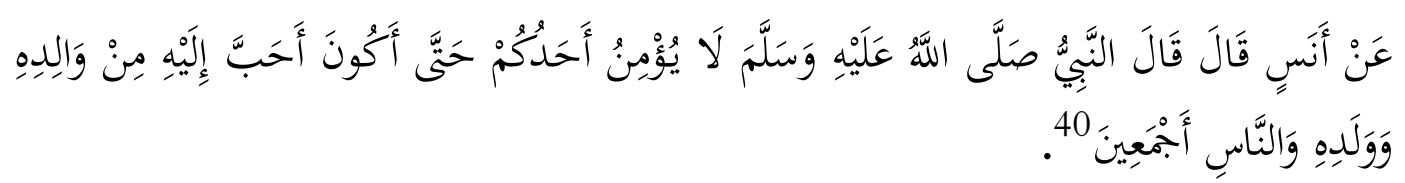

${ }^{39}$ Bukhari, al-Jami' al-Sahih al-Mukhtasar, bab Kaifa Kanat Yamini al-Nabi Saw., Juz. VII, h. 2445. 
Artinya:

Dari Anas berkata, Nabi saw., bersabda: Tidak sempurna iman seseorang di antara kamu, sehingga aku dicintai olehnya, lebih dari cintanya kepada anaknya, orang tuanya, dan seluruh manusia lainnya.

Penyebutan "seluruh manusia" setelah menyebutkan "Orang tua" dan "Anak" merupakan penyebutan sesuatu yang umum setelah menyebutkan sesuatu yang khusus. Penyebutan "seluruh manusia" juga meliputi diri sendiri. Sedangkan penyebutan orang tua lebih didahulukan daripada penyebutan anak, karena dari segi waktu, orang tua lebih dahulu ada, juga dari sisi kehormatannya. Dalam riwayat lain, didahulukan penyebutan anak daripada orang tua, tujuannya adalah untuk menjelaskan besarnya kasih sayang seseorang terhadap anaknya. ${ }^{41}$

Dengan demikian, hadis di atas merupakan dalil tentang wajibnya mencintai Nabi saw., dengan kualitas cinta tertinggi. Yakni kecintaan yang benar-benar melekat di hati yang mengalahkan kecintaan terhadap apapun dan siapapun di dunia ini. Bahkan meskipun terhadap orang-orang yang paling terdekat, seperti anak-anak, ibu, bapak dan keluarga. Bahkan kecintaan kepada Rasulullah saw., itu harus pula mengalahkan kecintaan terhadap diri sendiri.

Dalam sebuah hadis diceritakan bahwa ketika Umar berkata kepada Rasulullah saw., "sesungguhnya engkau wahai Rasulullah, adalah orang yang paling aku cintai daripada segala sesuatu selain diriku sendiri." Nabi kemudian menjawabnya "Tidak, demi zat yang jiwaku ada di tangan-Nya, sehingga aku lebih engkau cintai dari dirimu sendiri”. Dengan seketika Umar berkata kepada beliau, "Sekarang ini engkau lebih aku cintai daripada diriku sendiri." Maka Nabi saw., bersabda, "Sekarang (telah sempurna kecintaanmu (imanmu) padaku) wahai Umar. ${ }^{42}$

Ibn Hajar mengatakan bahwa sesuatu yang dicintai oleh seseorang tidak terlepas dari dua hal, yaitu; mencintai diri sendiri dan mencintai yang lain. Mencintai diri sendiri berarti keinginan agar dirinya tetap selamat dari segala

\footnotetext{
${ }^{40}$ Bukhari, Sahih al-Bukhari, bab Hubb al-Rasul saw., min al-Iman, Juz. I, h. 14.

${ }^{41}$ Abu al-Fadl Ahmad ibn 'Ali ibn Hajar al-'Asqalani al-Syafi'i, Fath al-Bari Syarh Sahih al-Bukhari, Juz. I (Beirut: Dar al-Ma'rifah, 1379), h. 59. Selanjutnya disebut Ibn Hajar.

${ }^{42}$ Bukhari, al-Jami 'al-Sahih al-Mukhtasar, Bab Kaifa Kanat Yamini al-Nabi Saw., Juz. VII, h. 2445.
} 
macam marabahaya. Inilah sebenarnya hakikat yang diinginkan oleh setiap orang. Adapun mencintai yang lain apabila dikaji lebih mendalam, sebenarnya adalah keinginan untuk memperoleh sesuatu yang berguna dengan bentuk yang beraneka ragam dalam waktu yang cepat ataupun lambat.

Apabila seseorang memperhatikan keberuntungan yang diperolehnya dari Rasulullah saw., yang telah mengeluarkannya dari gelapnya kekufuran kepada cahaya iman, secara langsung maupun tidak langsung, tentu ia akan sadari bahwa itulah yang menyebabkan dirinya mendapat kenikmatan abadi yang tiada putus. Orang tersebut akan mengetahui bahwa keuntungan itu lebih berharga dan lebih agung daripada keuntungan-keuntungan yang lain. Maka sudah sepantasnyalah kecintaan kepada Rasulullah saw., lebih besar bagiannya daripada kecintaan kepada selainnya. Sebab, keuntungan yang diperolehnya dari cinta tersebut lebih melimpah daripada keunt ungan yang diperoleh dari cinta selainnya. ${ }^{43}$

Berkaitan dengan hal di atas, Ibn Rajab yang dimaksud dengan mencintai Rasulullah saw., adalah mengikuti apa yang diperintahkannya atau mencintai apa yang dicintai oleh Nabi saw. Sebab cinta yang hakiki adalah mengikuti dan mencintai apa yang dicintai oleh orang yang dicintai. ${ }^{44}$

Di antara tanda mencintai Nabi adalah apabila dihadapkan pilihan antara Nabi saw., dan materi duniawi maka dia akan lebih mengutamakan Nabi saw., dari pada materi duniawi. Jika tidak, maka ia tidak dapat dikatakan mencintai Nabi saw. Dan demikian ini tidak terbatas pada ada atau tidak adanya Nabi saw., tapi mencintai Nabi saw., harus juga nampak ketika beliau telah wafat. Yaitu dengan menghidupkan sunnah-sunnah-Nya, menegakkan syariat yang diajarkannya. ${ }^{45}$

Solihan Zamakhsyari menyebutkan tanda-cinta kepada Rasulullah saw., ada 4, yaitu; 1) berkeinginan keras hidup bersama Nabi, 2) menjalankan perintah

\footnotetext{
${ }^{43}$ Ibn Hajar, Fath al-Bari Syarh Sahih al-Bukhari, Juz. I, h. 59.

${ }^{44}$ Abu al-Farj 'Abd al-Rahman ibn Ahmad ibn Rajab al-Hanbali, Jami' al- 'Ulum wa alHikam (Cet. I; Beirut: Dar al-Ma'rifah, 1408 H), h. 390. Selanjutnya disebut ibn Rajab al-Hanbali.

${ }^{45} \mathrm{Abu}$ al-Farj Zain al-Din 'Abd al-Rahman ibn Syihab al-Din al-Bagdadi dikenal dengan ibn Rajab, Fath al-Bari, Juz. I (Cet. II, al-Su'udiyah: Dar ibn Jauziy 1422 H.), h. 44. Selanjutnya disebut ibn Rajab.
} 
dan menjauhi larangannya, 3) melaksanakan sunnah dan menegakkan syari'ahnya, 4) megorbankan jiwa dan harta untuk membela Nabi saw. ${ }^{46}$

Dari uraian di atas dapat disimpulkan bahwa mencintai Nabi saw., berarti mengikuti dan meneladani Nabi saw., melakukan segala hal yang diwajibakan beliau, meninggalkan perkara-perkara yang dilarangnya, baik dalam akidah, ibadah maupun akhlak, meneladani perilaku beliau dan sebagainya.

Dengan demikian, seseorang yang mencintai Nabi saw., akan senantiasa berupaya melakukan apa yang disukai oleh beliau dengan penuh tanggung jawab serta ikhlas menjalankannya. Akan sangat mudah menyimpulkan bahwa seseorang berdusta dalam klaim cintanya, ketika diketahui bahwa yang bersangkutan, ternyata tidak melakukan apa saja yang diperintahkan kepadanya dan menjauhi apa yang dilarang. Atau juga ketika diketahui bahwa ia tidak pernah atau sangat jarang melakukan apa yang sangat disukai oleh Nabi Muhammad saw.

Kecintaan kepada Rasulullah saw., akan mengantarkan pelakunya memperoleh manisnya iman. Hal ini berdasarkan dari hadis Nabi sebagaimana yang diriwayatkan oleh Anas ibn Malik.

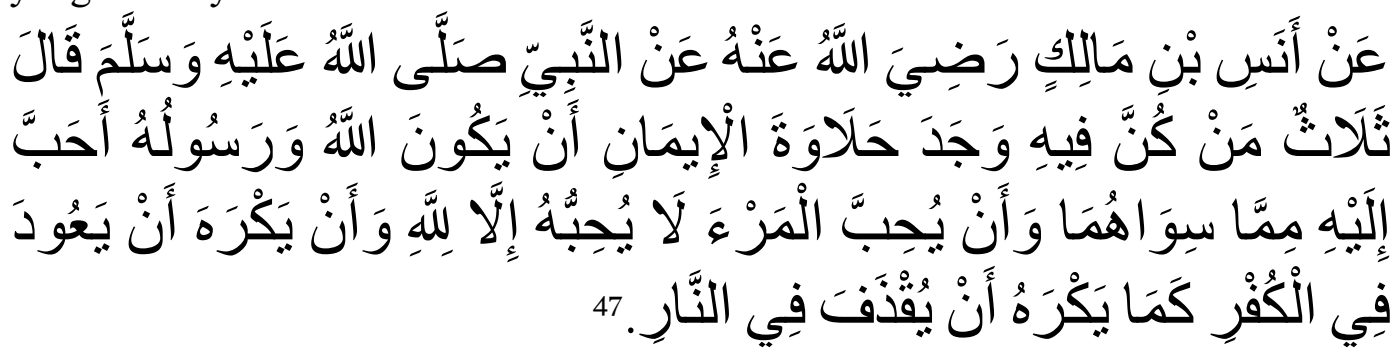

Artinya:

Dari Anas ra. dari Nabi saw., bersabda: "Tiga perkara yang apabila terdapat pada diri seseorang, niscaya ia akan merasakan manisnya iman, yaitu: Hendaknya Allah dan Rasul-Nya lebih dicintainya daripada yang lain. Hendaklah bila ia mencintai seseorang semata-mata karena Allah. Hendaklah ia benci untuk kembali kepada kekafiran sebagaimana ia benci kalau akan dicampakkan ke dalam api neraka.

\footnotetext{
${ }^{46}$ Solihan Zamakhsyari, Cinta Rasul Ciri-Ciri dan Buktinya, (Cet: I; Jakarta: Pustaka alKausar,2000), h. 30.

${ }^{47}$ Bukhari, Sahih al-Bukhari, bab Halawat al-Iman, Juz. I, h. 14.
} 
Imam al-Nawawi mengatakan makna dari kalimat "manisnya iman" adalah kelezatan dalam melakukan ketaatan dan berani menanggung beban berat ketika menjalankan agama serta lebih mengutamakan agama daripada dunia. Cinta kepada Allah swt., dapat terwujud dengan mengerjakan ketaatan dan menjauhi maksiat atau kedurhakaan. Demikian pula halnya cinta kepada rasul. ${ }^{48}$

Selain memperoleh manisnya iman, seorang yang mencintai Rasulullah saw., akan bersama dengannya di syurga. Hal tersebut sebagaimana yang disabdakan oleh Rasulullah saw., dalam sebuah hadisnya ketika ada seseorang yang datang bertanya kepadanya tentang hari kiamat.

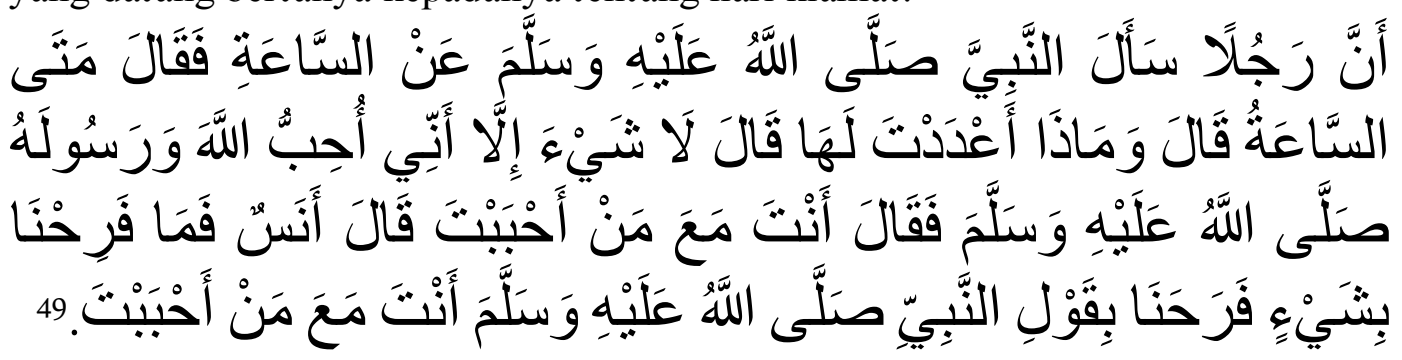

Artinya:

Ada seseorang yang bertanya kepada Nabi saw., tentang hari kiamat. Katanya; Kapan terjadinya hari kiamat?. Beliau balik bertanya kepada orang itu; Apa yang telah kamu siapkan untuk menghadapinya?. Orang itu menjawab; Tidak ada. Kecuali, aku mencintai Allah dan Rasul-Nya. Maka beliau berkata: Kamu akan bersama orang yang kamu cintai.

Lewat hadis di atas dipahami bahwa seseorang akan dikumpulkan bersama orang yang dia cintai. Namun bagaimana jika kedudukan mereka di surga memiliki tingkatan yang beragam (berbeda)?. Apakah masih tetap dikatakan bersama?. Berkaitan dengan hal ini, Ibn Hajar al-Asqalani mengungkapkan bahwa kebersamaan dapat terealisasi meskipun hanya dengan berkumpulnya pada suatu sisi, bukan pada semua sisinya. Oleh karena itu, jika

${ }^{48}$ Abu Zakariya Yahya ibn Syaraf al-Nawawi, al-Manhaj Syarah Sahih Muslim, Juz. II (Beirut: Dar Ihya' al-Turas al-'Arabi, 1392 H.), h. 13.

${ }^{49} \mathrm{Al}$-Turmuzi, Sunan al-Turmuzi, bab An al-Mar'u Ma'a Man Ahabba, Juz. IV, h. 595. 
semuanya masuk ke dalam surga, kebersamaan itu sudah terealisasi meskipun dengan tingkatan surga yang berbeda derajat. ${ }^{50}$

Dengan demikian, dapat dipahami bahwa seseorang yang benar-benar mencintai Nabi akan bersama dengannya. Dalam konteks ini, seseorang yang mencintai Nabi akan ditempatkan bersama dengan Nabi dalam surga sekalipun tidak sama kelasnya. Tentunya kelas surga Nabi yang paling tinggi, karena amaliah beliau yang tidak sama dengan manusia biasa.

\section{Penutup}

Berdasarkan penjelasan sebelumnya maka dapat dibuat simpulan sebagai berikut:

1. Hadis tentang mencintai Rasulullah bagian dari kesempurnaan Iman yang diriwayatkan oleh Ibn Majah berkualitas sahih dan dapat diamalkan. Hal tersebut berpijak pada 3 hal yaitu;

2. Mencintai Rasulullah berarti mengikuti dan melakukan segala hal yang diwajibakan oleh beliau, meninggalkan perkara-perkara yang dilarangnya, baik dalam akidah, ibadah maupun akhlak, meneladani perilaku beliau dan sebagainya. seseorang yang mencintai Nabi saw., akan senantiasa berupaya melakukan apa yang disukai oleh beliau dengan penuh tanggung jawab serta ikhlas menjalankannya. Kecintaan kepada Rasulullah saw., akan mengantarkan pelakunya memperoleh manisnya iman dan mengantarkannya bersama dengan Rasulullah saw., di syurga.

\section{DAFTAR PUSTAKA}

Al-Quran al-Karim.

A.W. Munawwir, Kamus al-Munawwir Arab-Indonesia. Yogyakarta: Pondok Pesantren al-Munawwir, 1984.

Afriqi, Muhammad ibn Mukrim Ibn Manzur. Lisan al-Arab, Juz. II al-Qahirah: Dar al-Maarif, t.th.

Ahmad, Arifuddin. Paradigma Baru Memahami Hadis Nabi. Cet. I; Jakarta: Renaisan, 2005.

al-Asbahani, Abu Nu'aim Ahmad ibn 'Abdillah ibn Ahmad ibn Ishaq ibn Musa ibn Mahra. Ma'rifat al-Sahabah. Cet. I; Riyad: Dar al-Watan, 1998 $\mathrm{M} / 1419 \mathrm{H}$.

\footnotetext{
${ }^{50}$ Ibn Hajar, Fath al-Bari, Juz. X, h. 555.
} 
Al-Asqalani, Abu al-Fadl Ahmad ibn Hajar. Fath al-Bari Syarh Sahih al-Bukhari. Juz. I. Beirut: Dar al-Marifah, 1379. h. 57.

------. Tahzib al-Tahzib, Beirut: Dar al-Fikr, 1984.

Al-Bukhari, Abu Abdillah Muhammad bin Ismail. Sahih al-Bukhari. Cet. III; Beirut: Dar Ibn Kasir, 1407 H./1987 M.

al-Darimi, Abu Muhammad abd Allah ibn abd al-Rahman ibn al-Fadhl ibn Bahram ibn abd al-Samad. Sunan al-Darimi, juz III. Cet. I; Saudi: Dar alMugni, 2000.

Al-Mahamid, Ahmad Nashib. al-Hubb baina al-Abd wa al-Rabb, Terj. Ahmad Zubaidi, Memadu Cinta di Taman Islam. Cet: I; Solo: Era Intermedia, 2002.

al-Hadi, Abu Muhammad Mahdi Abd al-Qadir ibn Abd. Turuq Takhrij Hadis Rasulillah saw. Terj. Said Aqil Husain Munawwar dan Ahmad Rifqi Mukhtar, Metode Takhrij Hadis. Cet. I; Semarang: Dina Utama, 1994 M.

al-Hanbali, Abu al-Farj 'Abd al-Rahman ibn Ahmad ibn Rajab. Jami' al-'Ulum wa al-Hikam. Cet. I; Beirut: Dar al-Ma'rifah, $1408 \mathrm{H}$.

al-Mizzi, Abu al-Hajjaj Yusuf ibn al-Zaki 'Abd al-Rahman. Tahzib al-Kamal, Cet. I; Beirut: Muassasah al-Risalah, 1400 H./1980 M.

al-Nasai, Abu Abd al-Rahman Ahmad ibn Syuaib ibn Ali al-Khurrasani. Sunan al-Nasai. Cet. II; Hilb: Maktabah al-Matbua al-Islamiyah, 1986.

al-Nawawi, Abu Zakariya Yahya ibn Syaraf. al-Manhaj Syarah Sahih Muslim. Beirut: Dar Ihya' al-Turas al-' Arabi, 1392 H.

Al-Syarif, Mahmud ibn. al-Hubb fi al-Qur'an, Terj. Yusuf Hanafi dan Abdul Fattah, al-Qur'an Bertutur Tentang Cinta. Cet. I; Yogyakarta: Cahaya Hikmah, 2003.

al-Zahabi, Muhammad ibn Ahmad ibn 'Usman. Tazkirat al-Huffaz. Cet. I; Beirut: Dar al-Kutub al-'Ilmiyah, 1998 M/ 1419 H.

Damis, Rahmi. Wawasan al-Quran Tentang al-Mahabbah. Disertasi Doktor, Program Pasca Sarjana Uin Alauddin Makassar, 2010.

Departemen Pendidikan Nasional, Kamus Besar Bahasa Indonesia Pusat Bahasa. Jakarta; Gramedia Pustaka Utama, 2008.

Gazali, Abu Hamid Muhammad ibn Muhammad. Ihya Ulum al-Din, Juz. IV. Beirut: Dar al-Marifah, t. th.

Hanbal, Abu 'Abdillah Ahmad ibn Muhammad ibn. Musnad Ahmad ibn Hanbal, Juz. III, Cet. I; Beirut: 'Alam al-Kutub, 1419 H./1998 M.

Ismail, M. Syuhudi. Kaedah Kesahihan Hadis: Telaah Kritis dan Tinjauan dengan Pendekatan Sejarah. Cet. III; Jakarta: Bulan Bintang, 2005.

Jauziyah, Abu Abd Allah Muhammad ibn Abu Bakar Ayyub al-Zari Ibn Qayyim. Raudat al-Muhibbin wa Nuzhat al-Musytaqin. Beirut: Dar al-Kutub alIlmiyah, $1412 \mathrm{M} / 1992 \mathrm{H}$.

Khatib, Muhammad Ajjaj. Usul al-Hadis Ulumuh wa Mustalahuh. Beirut: Dar alFikr, 1409 H./1989 M.

Majah, Abu 'Abdillah Muhammad ibn Yazid al-Qazwini Ibn. Sunan Ibn Majah, Juz. I (Beirut: Dar al-Fikr, t.th. 
Maharani, Sabrina. Filsafat Cinta. Cet. I; Jogjakarta: Garasi, 2009.

Nasution, Harun. Falsafat dan Mistisisme dalam Islam. Cet. IV; Jakarta: Bulan Bintang, 1985.

Naisaburi, Abu al-Husain Muslim bin al-Hajjaj bin Muslim al-Qusyairi. Sahih Muslim. Beirut: Dar al-Jil, t.th.

Rajab, Abu al-Farj Zain al-Din 'Abd al-Rahman ibn Syihab al-Din al-Bagdadi ibn Fath al-Bari, Cet. II, al-Su'udiyah: Dar ibn Jauziy 1422 H.

Ridha, Abdurrasyid. Memasuki Makna Cinta. Cet: III; Yogyakarta: Pustaka Pelajar, 2004.

Shihab, M. Quraish. Secercah Cahaya Ilahi, Hidup Bersama al-Quran. Cet. I; Bandung: Mizan, 2013.

Tasbih. Menemukan Hakekat Cinta Melalui Hadis Nabi Saw, Jakarta: Orbit Publishing, 2010.

Wensinck, A.J. Terj. Muhammad Fuad 'Abd al-Baqi, Mu'jam al-Mufahras li Alfaz al-Hadis al-Nabi, Juz. I. Brill: Laeden, 1936 H.

Zakariya, Abu Husain Ahmad ibn Faris. Mujam Maqayis al-Lugah. Beirut: Dar al-Fikr, 2002.

Zamakhsyari, Solihan. Cinta Rasul Ciri-Ciri dan Buktinya. Cet: I; Jakarta: Pustaka al-Kausar, 2000. 